\title{
On the destructive production of food: some lessons from South America
}

\author{
Gastón Gordillo ${ }^{1}$ \\ University of British Columbia, Canada
}

\begin{abstract}
This essay offers some general reflections on the destructive dimensions of corporatized forms of food production in contemporary South America. The dialectic of production and destruction that has long defined capitalism has too often been figured as "creative destruction", a phrase that can make the negative social and environmental impact of food commodity production seem to be something acceptable and even positive. The authors who contributed to this Special Section on Production/destruction in Latin America reveal, in contrast, that destruction has been integral to industrial or large-scale forms of food production in different parts of the continent. These articles remind us that the creation of a less destructive, more egalitarian world requires (among other things) not only the creation of renewable forms of energy but also a radical rethinking of the ways in which food is produced, distributed, and consumed. And the experience of South America in the past decade teaches us about the political limits of more progressive models of accumulation that, for all their merits, did not dare to delink the production of food from the short-sighted nature of corporate models that prioritize profits and hyper-productivity over social justice and sustainability.
\end{abstract}

Key words: Creative destruction; destructive production; ruination; rubble; food; commodities

\section{Résumé}

Ce commentaire offre des réflexions générales sur les dimensions destructrices de la production alimentaire par les entreprises de l'Amérique du Sud contemporaine. La dialectique de la production et de la destruction qui a défini le capitalisme a souvent été considérée comme une «destruction créative». Cette phrase fait que la production commerciale à grande échelle semble être acceptable et même positive, malgré ses impacts sociaux et environnementaux négatifs. Les auteurs qui ont contribué à cette section spéciale sur la production/la destruction en Amérique latine révèlent, en revanche, que la destruction a fait partie intégrante de la production industrielle à grande échelle dans tout le continent. Ces articles nous rappellent que la création d'un monde moins destructif et plus égalitaire exige la création d'énergies renouvelables, mais aussi une repensation radicale de la manière dont les aliments sont produits, distribués et consommés. Et l'expérience de l'Amérique du Sud au cours de la dernière décennie nous apprend qu'il existe des limites politiques aux modèles progressifs d'accumulation. Ceux-ci ne délignent pas la production de nourriture de la pensée corporelle à courte vue qui privilégie les bénéfices et l'hyperproductivité par rapport à la justice sociale et à la durabilité.

Mots clés: destruction créative; production destructrice; ruine; décombres; aliments; commodités

\section{Resumen}

Este ensayo ofrece algunas reflexiones generales sobre las destructivas dimensiones de las formas corporativizadas de la producción alimentaria en Sudamérica contemporánea. La dialéctica de producción y destrucción que por mucho tiempo ha definido al capitalismo, ha sido representada como una "destrucción creativa", frase que puede hacer ver el negativo impacto social y ambiental de la producción alimentaria, como algo aceptable, incluso positivo. Los autores que contribuyeron a esta sección especial sobre Producción/Destrucción en América Latina revelan, por el contrario, que la destrucción ha ido a la par con

\footnotetext{
${ }^{1}$ Dr. Gastón R. Gordillo, Professor, Department of Anthropology, University of British Columbia. 6303 NW Marine Drive, Vancouver, BC V6T 1A9, Canada. Email: gordillo "at" mail.ubc.ca. I would like to thank Casey Walsh and Javiera Barandiaran for their generous invitation to be the keynote speaker in the workshop Production/destruction: Latin American environments at UC Santa Barbara and also to the participants at this event for their valuable comments and feedback. This is the fifth article in Javiera Barandiarán and Casey Walsh (eds.). 2017. "Production/destruction in Latin America", Special Section of the Journal of Political Ecology 24: 716-800.
} 
formas de producción alimentaria industriales y a gran escala en diferentes partes del continente. En este sentido, estos artículos nos recuerdan que la creación de un mundo menos destructivo, más igualitario demanda (entre otras cosas) no solamente la creación de formas renovables de energía, sino también una reformulación radical de las formas en que los alimentos son producidos, distribuidos y consumidos. Además, la experiencia de Sudamérica en la década pasada, nos enseña sobre los límites políticos de modelos más progresivos de acumulación que, por todos sus méritos, no se atreven a desarticular la producción alimentaria de la naturaleza miope de los modelos corporativos que priorizan las ganancias y la hiper-productividad sobre las justicia social y la sustentabilidad.

Palabras clave: Destrucción creativa, producción destructiva, ruina, escombro, alimento, mercancía

Mainstream debates about global warming and the environmental crisis affecting the planet tend to focus on the negative impact of the use of fossil fuels such as oil and coal. But the essays of this special issue on Production/destruction: Latin American environments remind us that large-scale food production also creates profound forms of environmental disruption and is, in addition, one of the most important contributors to climate change. This relative silencing of the disruptive force of the food industry is partly made possible by the fact that producing "food" seems like a naturally benign practice aimed at "feeding the world", as the apologists for industrialized agriculture recurrently argue. When this destruction is so obvious that it cannot but be (partly) acknowledged, for instance in the deforestation by soy-farming and cattle-ranching in South America, it is often justified as the unfortunate side-effect of capitalism's "creative destruction." As Barandiaran and Walsh remind us in the introduction (2017), this has become the most popular phrase to name the dialectic of production/destruction that has defined capitalism as well as the type of disruptions documented in this Special Section. And while the term has been used by Marxist authors such as David Harvey (2006), the trope of "creative destruction" usually operates as an ideological mechanism of disregard, which by qualifying destruction as "creative" implies that it is in the last instance something positive and worth pursuing. This is why I have elsewhere proposed that the dialectic of production/destruction that defines capitalism could be more accurately rephrased as "destructive production", a term that while acknowledging that capitalism can, indeed, be extremely productive also makes apparent that this productivity generates massive forms of ruination that are not sustainable in the long run (Gordillo 2014).

The rich ethnographic and historical material presented by these case-studies provide ample evidence of the environmental and social destruction brought about by large-scale forms of food production in different parts of South America, namely: the contamination of the ocean, the decimation of local fish species, and the ruination of local livelihoods produced by salmon farms in southern Chile; the deforestation of the rainforest of Brazilian Amazonia to make space for cattle-ranching; the appropriation of water and the erosion of local forms of peasant livelihood in the Ecuadorian highlands by broccoli plantations; and the contamination and negative health effects caused by the intense use of synthetic nitrogen as fertilizer in agriculture. While the authors analyze these forms of ruination from different angles and through different lenses, they all show, first, that the rubble generated by them is usually located far from the places where these commodities (salmon, beef, broccoli, and other crops) are consumed. The subordination of food production to transnational hierarchies of power is particularly clear in Gerhart's and Partridge's articles (2017), which respectively show that the salmon farmed in southern Chile and the broccoli harvested in central Ecuador are promptly shipped off to satisfy the demands of well-off consumers in the global north. In the essay by San Martín (2017), the transnational dimensions of nitrogen consumption in agriculture in Chile have more openly political but also contradictory dimensions. San Martín shows how, on the one hand, this processes was shaped by the Cold War and in particular the efforts by the United States to alleviate poverty in Latin American through a Green Revolution that would ward off a Communist Revolution; but he also shows how, on the other hand, in the 1960s local research in Chile on nitrogen loss led to the growing awareness of its negative impact on the environment and human health - a process nonetheless curbed by the military coup against President Allende in 1973. In his article, Hoelle (2017) outlines the transnational dimensions of food production in the debates that took place in the 1980s about the destruction of the rainforests of Latin America to create "cheap beef for North American hamburgers." Yet Hoelle also shows that cattle-ranching in Amazonia is not reducible to global demands, for most of the beef generated in the region is consumed either locally or in the rest of Brazil. 
In fact, what makes the essay by Hoelle particularly fascinating is his analysis of the cultural value of beef in the state of Acre, where most locals view it as the most prestigious and nutritious form of food and, for this reason, are ready to disregard that cattle-ranching has implied the destruction of vast areas of rainforest. This spatial and affective disconnect between the consumers of certain food items and the places that have been ruined by their production is certainly a phenomenon that is present all over the world. Another example that has also negatively affected the tropical forests of South America is the expansion of soy farming in Brazil and Argentina to produce soy meal for pig farms in China and Europe, where most consumers of pork are oblivious to the negative environmental impact of their consumption patterns.

Another thread connecting some of these articles is the fact that the large-scale farming of food, and its resulting generation of debris, is not limited to land but has expanded, first, into the ocean. Gerhart's account of the spatial expansion of salmon farms along the coast of southern Chile is particularly powerful (2017). His article shows, first, that the neoliberal administrations that have ruled this country for decades have effectively privatized the Chilean seas by giving them in concession to farming corporations. Further, Gerhardt also shows that the salmon industry's intrinsic propensity to contaminate local waters with pathogens (generated by the farms' high density of highly medicated fish), and therefore its tendency to undermine its own conditions of reproduction, has made many of these companies move operations south into less densely farmed areas, thereby expanding the reach of their capacity to generate what he rightly calls "ecological rubble." In turn, Partridge's (2017) account about the conflict between for-export broccoli plantations and local peasant communities in Ecuador adds another fascinating dimension to the expansive spatiality of destructive food production: the fact that broccoli plantations have expanded their power into the atmosphere through the use of "anti-hailstone cannons." Residents blame the use of this technology for having disrupted and diverted rainstorm patterns in surrounding areas, as part of an overall sense that elites cultivating broccoli for first-world consumers are appropriating local sources of water for irrigation and in general undermining local forms of sovereignty. The sense that these plantations are trying to take over the skies and disrupt rain patterns is further reinforced by local accounts of mysterious planes projecting "lasers" or dropping "chemical bombs" to disperse clouds. While some of these rumors (unlike the use of anti-hailstone cannons) remain unconfirmed, they articulate the largely correct perception that corporate forms of food production have aggressively expanded their operations into areas that only a few decades ago were beyond their direct reach and control.

These articles also bring to light that the destructive production of food has been a defining feature of the countries that participated in the South American "left turn" of the first decade of the century, a "turn" that has now clearly come to an end. The progressive social policies implemented by these governments, as documented by Hoelle and Partridge in the cases of Brazil (under presidents Lula and Dilma) and Ecuador (under president Correa) respectively, certainly improved people's standard of living and empowered some forms of grassroots participation, either through the expansion of social programs and basic infrastructures in the case of Amazonia or through the introduction of constitutional changes in Ecuador and Bolivia about the right to collective wellbeing (El Buen Vivir, or Harmonious Living). As shown by Partridge (2017), these are rights that residents in Ecuador have explicitly drawn from to oppose the elites running broccoli plantations. Yet it is also well-known that these same governments have aggressively encouraged highly destructive mining, oil, and agribusiness operations by multinational corporations, often relying on the violent repression of protests by local communities. These governments, in short, have subordinated domestic growth to the global demand for commodities, not unlike the more openly neoliberal administrations in Chile or Peru.

These articles, to conclude, remind us that the creation of a less destructive, more egalitarian world demands (among other things) not only the creation of renewable forms of energy but also a radical rethinking of the ways in which food is produced, distributed, and consumed. And the experience of South America in the past decade teaches us about the political limits of more progressive models of accumulation that, for all their merits, never dared to delink the production of food from the short-sighted nature of corporate models that prioritize profits and hyper-productivity over social justice and sustainability. 


\section{References}

Barandiarán J. and C. Walsh. 2017. Production/destruction in Latin America. Journal of Political Ecology 24: 716-725.

Gerhart, A. 2017. Petri dishes of an archipelago: the ecological rubble of the Chilean salmon farming industry. Journal of Political Ecology 24: 726-742.

Gordillo, G. 2014. Rubble: the afterlife of destruction. Durham N.C.: Duke University Press. Academia, intro

Harvey, D. 2006. Neo-liberalism as creative destruction. Geografiska Annaler B: Human Geography 88 B: 145-158.

Hoelle J. 2017. Jungle beef: consumption, production and destruction and the development process in the Brazilian Amazon. Journal of Political Ecology 24: 743-762.

Partridge, T. 2017. Resisting ruination: resource sovereignties and socioecological struggles in Cotopaxi, Ecuador. Journal of Political Ecology 24: 763-776.

San Martín, W. 2017. Nitrogen, science, and environmental change: the politics of the green revolution in Chile and the global nitrogen challenge. Journal of Political Ecology 24: 777-796. 